\title{
The Multitask Theory of State Enterprise Reform: Empirical Evidence from China
}

\author{
By Chong-En Bai, Jiangyong Lu, and Zhigang Tao*
}

The reform of China's state-owned enterprises (SOEs) has been characterized by a gradual and selective approach. In fact there was no privatization at all until the mid-1990s, some 15 years after China started its economic reform. Despite years of economic reform, state ownership remains significant in the economy. Most of the SOEs are unprofitable and the few exceptional ones tend to be sheltered by government protection in selected industries. Yet China has been enjoying one of the most spectacular growth experiences in world history, and much of the growth is driven by non-state-owned enterprises (non-SOEs), including foreign-invested enterprises operating in China and China's own private enterprises.

Given the poor financial performance of SOEs, the coexistence of state ownership and private ownership in China is a puzzling phenomenon. Does state ownership exist solely for the benefit of politicians, as is modeled by Andrei Shleifer and Robert W. Vishny (1994), or has state ownership played any role in China's spectacular growth? Is there any rationale behind China's gradual and selective approach toward privatizing its SOEs? What types of SOEs does the Chinese government choose to privatize? What are the consequences of privatization? In this paper, we offer a theory of SOE reform in China, and make predictions regarding the types of SOEs to be chosen for privatization and the results of privatization. We then present empirical evidence supporting the basic premise of the theory and its theoretical predictions.

\footnotetext{
* Bai: Department of Economics, Tsinghua University, Beijing, China 100084 and School of Economics and Finance, University of Hong Kong (e-mail: baichn@em. tsinghua.edu.cn); Lu: Center for China in the World Economy, Tsinghua University, Beijing, China 100084 (e-mail: lujy3@em.tsinghua.edu.cn); Tao: Faculty of Business and Economics, University of Hong Kong, Pokfulam Road, Hong Kong (e-mail: ztao@hku.hk).
}

\section{Social Stability and China's SOE Reform}

Before China started economic reform in 1979, the government planned all economic activities. In this system, all the firms were state owned or de facto state owned. These firms received funding from the government bank according to the direction of the Central Planning Commission. They produced products that were usually in short supply; sold them at a price determined by the government; and did not face any competitive pressure. They paid workers low salaries but guaranteed their lifetime employment. They managed workers' pensions and provided many other services, including health care and education expenses for workers' children. Because their objective was not to pursue profit, the firms had little incentive to deviate from the plan. Meanwhile, despite their low income, workers could make ends meet because they received rations of many important products at low prices, as well as some services provided by their employers for free.

Despite its seeming stability, this system was very inefficient. Enterprises and individuals had no incentives, nor did they have the freedom to improve efficiency. Furthermore, the system left two other legacies. There was no social security system that was independent of the SOEs, and the financial system was very weak because all financial activities were carried out by one bank which served only as the cashier of the central planner.

Economic reform started in 1979. At first, SOEs were given more autonomy in their operations, and restrictions on entry by nonSOEs were gradually relaxed. Ownership reform started much later. With the massive entry of non-SOEs, and the gradual privatization of SOEs, two types of ownership came to coexist. SOEs now have to compete with nonSOEs in the market. Being grossly inefficient 
and ill-prepared for market competition, SOEs have been losing to non-SOEs in every possible measure of performance. Meanwhile, SOEs are still subject to restrictions on firing workers, and they have to honor their commitment to a large number of retired former employees. This makes the situation of SOEs even worse. Studies have revealed that there is as much as 30 percent surplus labor in China's SOEs, and a large amount of debt has been accumulated by them.

In a mature market economy, it is more efficient for firms to fire surplus labor and let the independent social security system provide welfare to these workers before they find new jobs. There is, however, no well-functioning independent social security system in China. Firms have to maintain the employment of, or provide welfare to, their surplus workers, which contributes to social stability. Therefore, firms in China face the multiple challenges of production and maintaining social stability, the latter of which has an effect on the performance of all other firms in the economy. Bai et al. (2000) offer a multitask theory of SOE reform that captures the production versus social stability trade-off. Non-SOEs with strong incentives for production have little interest in providing social stability. SOEs, however, do not mind keeping surplus labor on the payrolls, given their muted incentives for production. Three results follow from the theory. First, given that the existing level of social stability is low, it is optimal for the government to keep a fraction of SOEs as a second-best way of maintaining social stability. Second, as a result of multitasking, SOEs' financial performance is inevitably poorer than that of non-SOEs. This is not only because SOEs have to spend resources on maintaining social stability, but also because they are given low-profit incentives by the government. Third, when the level of social stability is higher, the government should speed up the process of privatization.

The weakness of the financial system also implies a negative external effect of privatizing on SOEs. When an SOE is privatized, its high debt has to be restructured in order for its new owner to be willing to acquire the firm. With an efficient financial system, the restructuring of the debt should benefit the bank and the new and old owners of the firm. China's banks, however, are often under the strong influence of local government, and are sometimes susceptible to corruption. The privatization of an SOE often leads to the write-off of an unnecessarily large amount of debt. This has a negative effect on the health of the financial system, causing damage to the whole economy. This effect provides another link between SOE reform and social stability.

The multitask theory of SOE reform suggests that SOEs have played an important role in China's economic growth, namely, providing social stability at the expense of financial performance, and it offers a rationale for China's gradual and selective approach to privatizing its inefficient SOEs. Indeed, throughout the reform process, Chinese leaders have made numerous policy speeches emphasizing the importance of social stability. As SOEs are but second-best arrangements for maintaining social stability, the government has made great effort in building an efficient and independent social security system and cleaning up its financial system. Anecdotal evidence also suggests that the government has accelerated (or slowed down) its speed of privatization when there is more (or less) job opportunity for laid-off workers from non-SOEs.

The most direct evidence for our theory comes from studies on the consequences of privatization. Existing studies, for example, Jian Su and Gary Jefferson (forthcoming), have found significant improvements in firm profitability, a prediction of our theory. What is less clear is whether privatized firms would lay off workers and write off loans, two other predictions of our theory. Using a panel dataset of 2,866 of China's SOEs for the period of 1998 to 2003, Bai et al. (2005b) find that the number of employees in a privatized firm decreases with the extent of privatization, and that both the absolute amount of debt and the financial expenses to sales ratio also decrease with the degree of nonstate ownership. These results lend strong support to the multitask theory of SOE reform.

\section{Causes and Consequences of Privatizing China's SOEs}

The multitask theory of SOE reform has predictions on the types of SOEs to be chosen for 
privatization. Notice that, despite the importance of social stability, China's central and local governments have divergent interests in maintaining inefficient SOEs. This is because, due to labor migration and regional interdependence in the financial system, the negative impact of laying off surplus workers and writing off bad loans is not restricted to local regions. The local governments capture only a fraction of the external benefits of social stability and therefore do not have sufficient incentives to maintain social stability. The central government internalizes all the external effects of social stability, however, and has the proper incentive to maintain social stability. Yuanzheng Cao et al. (1999) also discuss the divergent interests of central and local government. SOEs in China are affiliated with the county, city, province, or central government. Thus, our theory predicts that the higher the affiliation of an SOE, the less likely it will be privatized.

The effect on social stability of privatization becomes stronger when the firm has more surplus labor. Therefore, the divergence of interests among different levels of government increases with the amount of surplus labor. Specifically, as the amount of surplus labor in an SOE increases, the cost of privatization in terms of damage to social stability increases, and the increase is faster for higher-level governments than for lower-level governments because the former internalize the negative externality to a greater extent. The benefit of privatizing an SOE also increases with its surplus labor as more cost saving can be realized after the surplus workers are laid off. The rate of increase in the benefit is the same for different levels of government, however. Comparing the changes in costs and benefits, the cost may increase faster than the benefit for higher-level governments and slower for lower-level governments. Consequently, the multitask theory predicts that there exists a government-affiliation level below which SOEs with more surplus labor are more likely to be restructured, but above which the opposite is true. A similar prediction can also be made about the level of debt.

These implications of the multitask theory regarding the effects of government affiliation and the amounts of surplus labor and debt on the privatization decision can be empirically tested. Using a panel dataset of 26,153 of China's
SOEs for the period of 1995 to 1997, Bai et al. (2005a) find strong empirical support for these implications.

An alternative theory regarding the relationship between the level of government affiliation and the likelihood of privatization of an SOE is that higher-level governments have stronger fiscal capability to bail out failing SOEs, and therefore SOEs affiliated with higher-level governments are less likely to be privatized. However, this theory has different implications from the multitask theory on the relationship between surplus labor and privatization. Specifically, the fiscal capability theory cannot explain why the central government is less likely to privatize firms with more surplus labor, while the multitask theory can.

The divergent interests of China's central and local governments also have implications for the consequences of privatization. Lower-level (such as county or city) governments like to dump those SOEs that are laden with surplus labor and debts. This implies that, with privatization of SOEs affiliated with the county or city governments, there will be substantial layoffs of surplus workers and massive write-offs of bad loans. In contrast, higher-level (provincial or central) governments care more about social stability, and they are reluctant to let go of those SOEs for which privatization would lead to labor layoffs and loan write-offs. This implies that there may not be any decrease in employment or debts with privatization of SOEs affiliated with the provincial or central governments. These differences in the consequences of privatization among firms with different levels of government affiliation may also be the result of different levels of government imposing different restrictions on the layoff of workers and write-off of debt in the process of privatization. Given that laying off unproductive workers and trimming excessive loans are essential to firm performance, it is expected that there will be significant improvements in firm profitability with privatization of SOEs affiliated with the county or city governments, but it may not be the case for SOEs affiliated with the provincial or central governments.

We test the predictions about the consequences of privatization given above using the same dataset as in Bai et al. (2005a). All firms 
in the sample were 100 percent state-owned in 1998 , but they were privatized at different times and to different degrees from 1999 to 2003. To control for potential selection bias problems, we estimate a firm fixed-effect model as in Roman Frydman et al. (1999). In addition, we compare the performance of the SOEs that were privatized between 1999 and 2002 with those that did not get privatized until 2003, in the time period between 1998 and 2002. The dependent variables are logarithm of employment, financial expenses to sales ratio, and operating income to sales. The key independent variables are the interaction terms between non-state ownership measuring the extent of privatization (denoted by NonSShr) and the dummy variables regarding the government affiliation levels of SOEs (denoted by county, city, province, and central). The estimation results are summarized as follows.

(1) logarithm of employment

$$
\begin{gathered}
=0.020 \text { NonSShr } * \text { County } \\
(0.012) \\
-0.078 \text { NonSShr } * \text { City } \\
(0.017) \\
+0.066 \text { NonSShr } * \text { Province } \\
(0.031) \\
+0.025 \text { NonSShr } * \text { Central } \\
(0.060)
\end{gathered}
$$

(2) financial expenses to sales ratio

$$
\begin{gathered}
=-0.006 \text { NonSShr*County } \\
(0.003) \\
-0.008 \text { NonSShr*City } \\
(0.004) \\
+0.003 \text { NonSShr*Province } \\
(0.007) \\
+0.019 \text { NonSShr } * \text { Central } \\
(0.013)
\end{gathered}
$$

(3) operating income to sales ratio

$$
=0.029 \text { NonSShr*County }
$$

$$
\begin{gathered}
+0.030 \text { NonSShr* City } \\
+\underset{(0.013)}{0.012 \text { NonSShr } * \text { Province }} \\
\text { - } 0.060 \text { NonSShr } * \text { Central } \\
(0.074)
\end{gathered}
$$

It is found that both the logarithm of employment and the financial expenses to sales ratio (measuring not only the impact of the decreasing amount of debt, but also that of the lower interests and commissions paid for the remaining debt) decrease with the extent of privatization for SOEs affiliated with the county or city governments, but the opposite holds for SOEs affiliated with the provincial or central governments. Consistently, there are significant gains in the operating income to sales ratio for privatizing SOEs affiliated with the county or city governments, but not for SOEs affiliated with the provincial or central governments. Wald test shows that the differences between the coefficients of the central or provincial government, and those of the city or county government, are statistically significant. These results support the implications of our theory.

In summary, we believe that the coexistence of SOEs and non-SOEs in China is a second-best arrangement that helps maintain social stability and thus protects the business environment of all firms. Empirical evidence about the types of SOEs to be privatized, and the consequences of privatization, all support our theory.

\section{REFERENCES}

Bai, Chong-En; Li, David D.; Tao, Zhigang and Wang, Yijiang. "A Multitask Theory of State Enterprise Reform." Journal of Comparative Economics, 2000, 28(4), pp. 716-38.

Bai, Chong-En; Lu, Jiangyong and Tao, Zhigang. "Divergent Interests between Central and Local Governments: Testing Theories of Public Ownership." Hong Kong Institute of Economics and Business Strategy Working Papers: No. 1143, 2005a.

Bai, Chong-En; Lu, Jiangyong and Tao, Zhigang. "How Does Privatization Work in China?" Unpublished Paper, 2005b. 
Cao, Yuanzheng; Qian, Yingyi and Weingast, Barry R. "From Federalism, Chinese Style, to Privatization, Chinese Style." Economics of Transition, 1999, 7(1), pp. 103-31.

Frydman, Roman; Gray, Cheryl; Hessel, Marek and Rapaczynski, Andrzej. "When Does Privatization Work? The Impact of Private Ownership on Corporate Performance in the Transition Economies." Quarterly
Journal of Economics, 1999, 114(4), pp. 1153-91.

Shleifer, Andrei and Vishny, Robert W. "Politicians and Firms." Quarterly Journal of Economics, 1994, 109(4), pp. 995-1025.

$\mathrm{Su}$, Jian and Jefferson, Gary. "Privatization and Restructuring in China: Evidence from Shareholding Ownership." Journal of Comparative Economics (forthcoming). 